\title{
The occurrence of a new species of Gomphocythere (Ostracoda, Limnocytheridae) in the Holocene of SE Turkey: the northernmost record for the genus
}

\author{
IAN BOOMER ${ }^{1, *} \&$ BEN GEAREY ${ }^{2}$ \\ ${ }^{1}$ School of Geography, Earth and Environmental Sciences, University of Birmingham, Edgbaston B15 2TT, UK \\ ${ }^{2}$ Institute of Archaeology and Antiquities, University of Birmingham Edgbaston B15 2TT, UK \\ ${ }^{*}$ Corresponding author (e-mail: i.boomer@bham.ac.uk)
}

\begin{abstract}
A new species of the genus Gomphocythere (Sars, 1924) from SE Turkey extends the known Holocene biogeographical range of this taxon northwards by $500 \mathrm{~km}$ although only sub-fossil remains have been discovered so far. The species has been recorded previously in open nomenclature, from a middle Pleistocene site in northern Israel but the genus Gomphocythere is particularly abundant and diverse in the large lakes of South and East Africa (e.g. Lakes Malawi, Tanganyika and Victoria). The closest relative of the new species, based on external carapace characteristics, is known to be alive today along one of the sources of the River Jordan, central Israel. This suggests the presence of a geographically distinct 'northern group' of Gomphocythere separated from the majority of known occurrences in eastern and southern Africa. J. Micropalaeontol. 29(2): 115-118, December 2010.
\end{abstract}

KEYWORDS: Ostracod, Limnocytheridae, Gomphocythere, biogeography, Turkey

\section{INTRODUCTION}

During archaeological investigations at the late prehistoric (Halaf Period, approximately 6500-5500 BC) 'tell' site of Domuztepe (Campbell et al., 1999; Carter et al., 2003) in SE Turkey $\left(37^{\circ} 19^{\prime} 10.96 \mathrm{~N}, 37^{\circ} 03^{\prime} 41.16 \mathrm{E}\right)$, a geoarchaeological survey of the alluvial plain surrounding the site was undertaken. This consisted of the recovery of sediment sequences with a hand-operated auger. Sub-samples from the deposits were subsequently analysed for a range of biological remains including diatoms, plant macrofossils and ostracods.

The genus Gomphocythere has hitherto been recorded almost exclusively from the late Cenozoic to Recent of the large lake systems of East Africa (Martens, 2002; Park \& Martens, 2001; Park et al., 2000; 2002), as well as smaller lacustrine systems in southern Africa and rivers in the Levant (Israel; Martens, 1993; Rosenfeld et al., 2004). Martens (1993) reviewed the taxonomy and zoogeography of the genus Gomphocythere and described a new, living species of the genus from the Nahal Dan, one of the sources of the River Jordan. He remarked that it was 'distinguished from all its congeners by the large elongated valves in both sexes'. That species was, at the time, the northernmost record for the genus. The new occurrences reported here extend the northern biogeographical limit of the genus by a further $500 \mathrm{~km}$.

In a later work, Park \& Martens (2001, pp. 144-145) commented on the possible synonymy between Gomphocythere and the South American genus Gomphodella (De Deckker, 1981). Notwithstanding these unresolved discussions, Gomphocythere is here considered to be restricted to Africa and the near east.

\section{STUDY AREA AND MATERIAL}

Domuztepe is located close to the northwestern edge of the Narl alluvial plain in south-central Turkey, c. $45 \mathrm{~km}$ from the town of Kahramanmaraş (Fig. 1). The archaeological site is a 'tell' (raised area of occupation material and structural remains) that rises to a height of $12 \mathrm{~m}$ above the surrounding flood plain and, at 20 ha in area, it is one of the largest-known late Neolithic settlements in the Middle East (Campbell et al., 1999). Immedi- ately to the north and west the land rises to form a series of low hills. The prehistoric phases of the site have been under investigation since 1995 (see Campbell et al., 1999; Carter et al., 2003). The site is located on the western edge of the $10 \mathrm{~km}$ wide Narli plain, which is mapped as 'old alluvium' and 'alluvium'; whilst to the north, south and west the land rises to form a series of hills which are mapped as dolomitic limestone (Geological Reconnaissance Maps of Turkey No. 44). An unnamed watercourse flows immediately to the west of the tell, draining into the

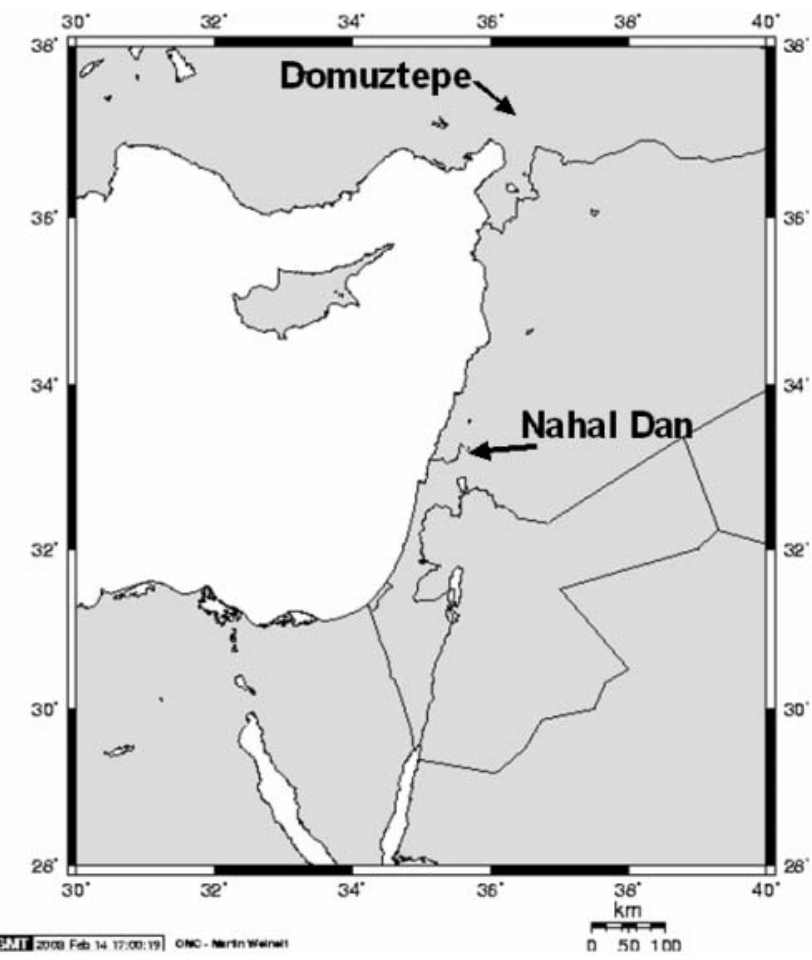

Fig. 1. Map showing location of Domuztepe archaeological site, SE Turkey and Nahal Dan, Israel. Map courtesy of OMC (Online Map Creation) at www.aquarius.ifm-geomar.de. 
Aksu River some $4 \mathrm{~km}$ to the north. This is now an 'underfit' river, but extensive spreads of gravels, which are currently being extracted for aggregates, indicate that prior to the current water abstraction, irrigation and management regime, it was previously a large and active fluvial system. Plant remains typical of wetland environments are ubiquitous in samples from the site's excavated layers, including those from which the ostracods were recovered (Cyperaceae (sedges), Juncus spp. (rushes), Schoenus nigricans (Black bog rush), Eleocharis sp. (Spike-rush)), indicating the prevalence of wetland environments throughout the late Holocene.

During two seasons of fieldwork a number of transects were cored using an Eijkelkamp 'gouge' corer. Boreholes were excavated in nine transects centred on and near to the tell. Borehole lithology was logged in the field and sub-samples were collected for later assessment and analysis. Selected sub-samples were examined for diatoms, ostracods and molluscs. The limited sampling programme was intended to assess only the potential of the deposits for more detailed study, it is one of these reconnaissance samples that yielded the present material.

There is a significant degree of lateral variation observed in the depositional environments adjacent to the main archaeological site. The sediments can generally be assigned to one of three main associations: dense clays; black mollusc-rich silts; and calcareous silts, clays and marls, all appear to be associated with flowing or standing-water bodies, some of which are clearly organic rich.

Samples from the calcareous silts and clays were assessed for calcareous microfossils. Samples were air-dried, disaggregated in $5 \% \mathrm{H}_{2} \mathrm{O}_{2}$, rinsed through a series of sieves and dried before picking under a binocular microscope. The most abundant - and only other ostracod species encountered in the samples - were assigned to the genus Candona. They were recorded in most of the samples investigated from this site and most probably belong to a single species of the group Candona sensu str. (sensu Meisch, 2000) but no intact adult valves were recovered. Candona is typical of fresh to slightly saline waters, usually as permanent habitats, but most occurrences do not appear to be in situ as adult and late juvenile valves are rare. This may indicate that some of the samples represent a slack-water depositional environment, downstream of the primary ostracod habitat. Interpreting these environments is currently somewhat complex. The deposits seem to have accumulated in a series of fresh, still or slowly flowing open-water environments, but there is evidence from both the lithology and biological remains for episodes of enhanced fluvial influence in the form of in-wash lenses and re-deposition of material.

One sample, from a single core consisting of calcareous silty-clay of probable mid-late Holocene age, yielded an ostracod assemblage that includes specimens of a single, new species of the limnocytherid genus Gomphocythere. The valves are well preserved, with no obvious evidence of dissolution. The approximate age of the sample was determined by its relative position, lying above a series of organic-rich deposits recorded across much of the site which date to between 17.4 and $8.5 \mathrm{ka} \mathrm{BP}{ }^{14} \mathrm{C}$. The ostracod sample comes from a sedimentary unit that is considered to be broadly equivalent to the major culturalbearing sediments.

\section{TAXONOMY (BY I. BOOMER)}

Family Limnocytheridae Klie, 1938

Subfamily Timiriaseviinae Martens, 1995

Genus Gomphocythere Sars, 1924

Gomphocythere geareyi Boomer, sp. nov. (Pl. 1)

2004 Cytheromorpha fuscata (Brady) Rosenfeld et al.: pl. 1, figs $12-14$.

Type species. Gomphocythere obtusata (Sars, 1910).

Derivation of name. After Dr Ben Gearey (University of Birmingham) who provided the sample from which the species was recovered.

Holotype. Plate 1 (figs 1, 3). Female, left valve, OS 16556 (Natural History Museum, London).

Paratypes. OS 16557-16562 (all Natural History Museum, London).

Material. 12 adult valves, 3 adult carapaces, 4 juvenile valves.

Type locality and level. Domuztepe, Turkey $\left(37^{\circ} 19^{\prime} 10.96 \mathrm{~N}\right.$, $\left.37^{\circ} 03^{\prime} 41.16 \mathrm{E}\right)$. All specimens recovered from a single sample (Core 3, Transect 9, depth $1.68 \mathrm{~m}$ ).

Description. Valves elongate, females elongate-quadrate in lateral view (males smaller and tapering slightly posteriorly), bearing shallow, regular fossae across much of the external surfaces. Anterior marginal area markedly flattened, flange extends beyond the selvage. A distinct shallow ridge or crest extends from the postero-ventral region running anteriorly along the ventro-lateral margin and ending at, but not crossing, the compressed anterior zone; the ridge is less distinct in males. Ventral ridges are noted in many species of Gomphocythere and the distinctive ventro-lateral rib in this new species is probably an extension of one of these. A few sparse pore conuli are noted along the anterior and posterior margins.

Hingement with a simple 'reversed' lophodont structure, smooth terminal elements in the left valve, smooth median bar in the right. Calcified inner lamella relatively narrow in adults, small vestibulum. Adductor muscle scars a sub-vertical row of four central, elongate scars and a single, rounded frontal scar. Two small, rounded mandibular scars are also observed. Regularly-spaced simple pore-canals perforate the carapace throughout. No living specimens were recovered.

Sexual dimorphism present but, as with the species described by Martens (1993) from Israel, the distinctive 'brood-pouches' in the females of the East African species appear to be reduced to a 'swelling' of the posterior third of the valves, in a similar style to that seen in the genus Metacypris, although by no means as distinct (see Pl. 1, fig. 4, dorsal view, female carapace; Pl. 1, fig. 5 , dorsal view, male carapace; also figure 2, lateral view female $\mathrm{RV}$ and figure 6, male RV). 


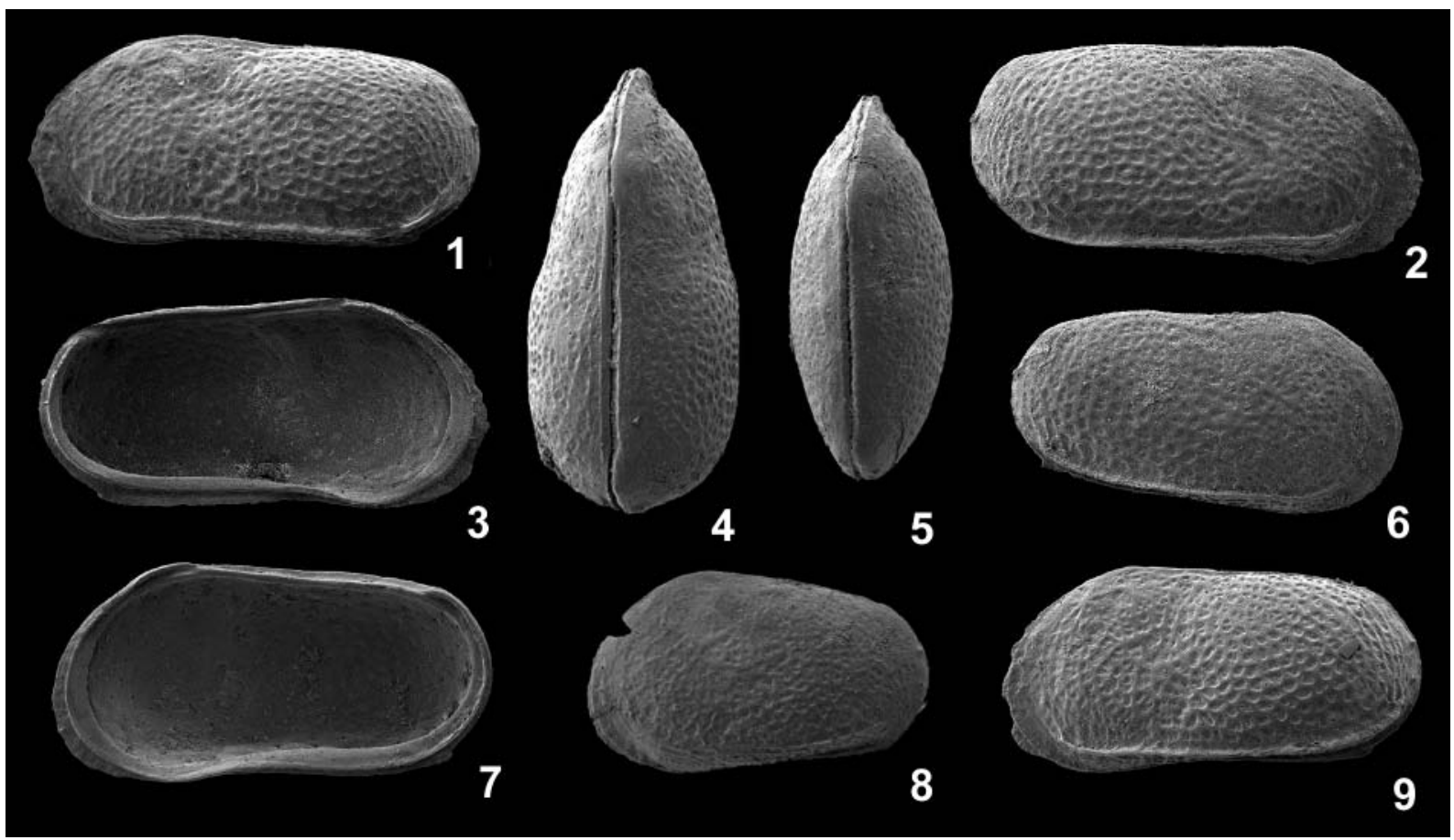

Explanation of Plate 1.

Gomphocythere geareyi sp. nov., from type level and locality. figs 1, 3. Holotype. OS 16555 Adult female LV, $660 \mu \mathrm{m}: \mathbf{1}$, ext. lat. $\times 76$; 3, int. lat. $\times 76$. fig. 2. Paratype. OS 16556 Adult female RV, $680 \mu \mathrm{m}$, ext. lat. $\times 74$. fig. 4. Paratype. OS 16557 Adult female carapace, $640 \mu \mathrm{m}$, dorsal view $\times 78$. Fig. 5. Paratype. OS 16558 Adult male carapace, $560 \mu \mathrm{m}$, dorsal view $\times 77$. Fig. 6. Paratype. OS 16559 Adult male RV, $530 \mu \mathrm{m}$, ext. lat. $\times 82$. Fig. 7. Paratype. OS 16560 Adult female RV, $630 \mu \mathrm{m}$, int. lat. $\times 78$. Fig. 8. Paratype. OS 16561 Juvenile A-1(?) LV, $420 \mu \mathrm{m}$ ext. lat. $\times 91$. Fig. 9. Paratype. OS 16562 Adult female LV, $630 \mu \mathrm{m}$, ext. lat. $\times 67$.

Remarks. Differs from G. ortali Martens, 1993 in possessing a distinct, shallow, longitudinal flange along the ventro-lateral margin. The new species is also somewhat more elongate in the females than $G$. ortali which also has males that appear more triangular in lateral view, the dorsal and ventral margins tapering towards the posterior. Martens (1993) also notes that the male vales of $G$. ortali are '... strongly sclerified and externally reticulated, but without ridges or crests'; however, a very weak ventral ridge can be seen on his male specimens (Martens, 1993, figs $1 \mathrm{E}, \mathrm{F}$ ) but these are weak or absent on the anterior half. A ventro-lateral ridge is clearly visible along the full length of the male valves of $G$. geareyi (Pl. 1, fig. 6, this work). The external ornamentation also differs slightly between the two species: in $G$. ortali the ornamentation consists of relatively regularly spaced and sized reticulae; but in G. geareyi the reticulae are somewhat smaller and there is some alignment parallel to the margins. In most other respects, such as internal features and dorsal outline, the two are very similar, suggesting a close phylogenetic relationship.

Carbonel et al. (1987) illustrated a species of Gomphocythere cf. angulata Lowndes, 1932 from the late Pleistocene of Lake Bogoria, Kenya, which is similar to G. geareyi in general outline and also possesses a ventro-lateral rib. The species from Lake Bogoria differs in the much finer degree of ornamentation, more inflated carapace and the possession of a narrow, compressed, dorsal marginal zone. It also has a greater number of antero- and postero-lateral pore conuli.

The only known previous record of $C$. geareyi comes from the Acheulian (mid-Pleistocene) Gesher Benot Ya'aqov archaeo- logical site in the Jordan Rift valley, northern Israel, where it was mis-identified as the fresh to low salinity species Cytheromorpha fuscata (Brady) known from NW Europe (e.g. Boomer \& Horne, 1991) and North America (e.g. Neale \& Delorme, 1985). By comparison with its co-occurring taxa at the Israeli site, G. geareyi is also considered to inhabit freshwater to oligohaline waters.

\section{ACKNOWLEGEMENTS}

David Horne (QM London) and Koen Martens (Nat. Hist. Mus., Brussels) are thanked for their initial comments on this material. KM and an anonymous reviewer are also thanked for their constructive comments. BG acknowledges the Wainwright Fund for generously providing funds to facilitate fieldwork.

\section{Manuscript received 11 June 2009}

Manuscript accepted 10 July 2010

Scientific editing by F. John Gregory

\section{REFERENCES}

Boomer, I.D. \& Horne, D.J. 1991. On Cytheromorpha fuscata (Brady). A Stereo-Atlas of Ostracod Shells, 18(13): 49-56.

Campbell, S., Carter, E., Healey, E., Anderson, S., Kennedy, A. \& Whitcher, S. 1999. Emerging complexity on the Kahramanmaras Plain, Turkey: The Domuztepe Project 1995-1997. American Journal of Archaeology, 103: 395-418.

Carbonel, P., Grosdidier, E. \& Peypouquet, J.-P. 1987. Les Ostracodes et l'évolution des milieux en termes hydrologiques. In: Tiercelin, J-J. et al.. (Eds), The Baringo-Bogoria Half Graben, Gregory Rift, Kenya. 30,000 years of hydrological and sedimentary history. Bulletin des 
Centres de Recherches Exploration-Production, Elf Aquitaine, 11(2): 249-540.

Carter, E., Campbell, S. \& Gauld, S. 2003. Elusive complexity: New data from late Halaf Domuztepe in south central Turkey. Paléorient, 29(2): $117-133$.

De Deckker, P. 1981. Taxonomy and ecological notes on some ostracods from Australian inland waters. Transactions of the Royal Society of Southern Australia, 105: 91-138.

Lowndes, A.G. 1932. Report on the Ostracoda. Mr Omer-Cooper's Investigation of the Abyssinian Fresh Waters (Dr. Hugh Scott's Expedition). Proceedings of the Zoological Society of London, 3: 677-708.

Martens, K. 1993. On the Taxonomy and Zoogeography of the genus Gomphocythere Sars, 1924 (Crustacea, Ostracoda), with the description of a new species from the Nahal Dan (Israel). Belgian Journal of Zoology, 123: 39-54.

Martens, K. 2002. On the evolution of Gomphocythere (Crustacea, Ostracoda) in Lake Nyassa/Malawi (East Africa), with the description of 5 new species. Hydrobiologia, 497: 121-144.

Meisch, C. 2000. Freshwater Ostracoda of Western and Central Europe. In: Schwoerbel, J. \& Zwick, P. (Eds), Suesswasserfauna von Mitteleuropa 8/3. Spektrum Akademischer Verlag, Heidelberg, 522 pp.

Neale, J.W. \& Delorme, L.D. 1985. Cytheromorpha fuscata: a relict Holocene marine ostracod from freshwater inland lakes of Manitoba Canada. Revista Española de Micropaleontologia, 17: 41-64.
Park, L.E. \& Martens, K. 2001. Four new species of Gomphocythere (Crustacea, Ostracoda) from Lake Tanganyika, East Africa. Hydrobiologia, 450: 129-147.

Park, L.E., Cohen, A.S. \& Martens, K. 2000. Ecology and speciation of the ostracod clade (Gomphocythere) in a tropical lake system, Lake Tanganyika, East Africa. Verhandlungen des Internationalen Verein Limnologie, 27: 1-5.

Park, L.E., Martens, K. \& Cohen, A.S. 2002. Phylogenetic relationships of Gomphocythere (Ostracoda) in Lake Tanganyika, East Africa. Journal of Crustacean Biology, 22: 15-27.

Rosenfeld, A., Nathan, Y., Feibel, C.S., Schilman, B., Halicz, L., Goren-Inbar, N. \& Siman-Tov, R. 2004. Palaeoenvironment of the Acheulian Gesher Benot Ya'aqov Pleistocene lacustrine strata, Northern Israel - lithology, ostracod assemblages and ostracod shell geochemistry. Journal of African Earth Sciences, 38: 169-181.

Sars, G.O. 1910. Zoological results of the 3rd Tanganyika expedition (1904-1905). Report on Ostracoda. Proceedings of the Zoological Society of London, 48: 732-760.

Sars, G.O. 1924. The fresh-water Entomostraca of the Cape Province (Union of South Africa). Part II: Ostracoda. Annals of the South African Museum, 20: 105-193. 